\title{
Rola, znaczenie i wyzwania wynikające ze wspótpracy uczelni wyższych technicznych z przedsiębiorstwami na przykładzie polskich politechnik
}

\author{
Mgr Justyna Dylik iD \\ Szkoła Główna Handlowa w Warszawie \\ Instytut Zarządzania \\ Zakład Zarządzania Przedsiębiorstwem
}

\section{Wprowadzenie}

Celem publikacji jest ukazanie roli i znaczenia współpracy pomiędzy uczelniami wyższymi technicznymi a małymi i średnimi przedsiębiorstwami w Polsce. W wyniku współpracy powstają nowe wyzwania, jakim muszą stawić czoła oba podmioty. Metodą badawczą, jaką posłużono się w trakcie badań, był wywiad telefoniczny z ekspertami lub brokerami informacji, którzy są zatrudnieni w centrach transferu technologii przy badanych politechnikach.

Celem badania było również uzyskanie odpowiedzi na pytania dotyczące doświadczeń we współpracy politechnik z przedsiębiorstwami. Szczególnie ważne było uzyskanie odpowiedzi na pytanie określające zakres, jakość oraz warunki współpracy politechnik z małymi i średnimi przedsiębiorstwami. Szczególnie istotne były pytania dotyczące działań mających na celu podjęcie współpracy, a także czynników motywujących i ograniczających współpracę. Uzyskane w ten sposób wyniki pozwoliły na przygotowanie interesujących wniosków i rekomendacji mających ulepszyć współpracę. Ankieta przeprowadzona była w formie wywiadu telefonicznego, podczas którego zostało zadanych dziesięć otwartych pytań. Opracowanie to, stanowiąc empiryczną podbudowę poznawczą, może być punktem wyjścia do kolejnych rozważań na temat wzrostu znaczenia oraz roli współpracy i lepszego poznania nowych wyzwań w rozwoju współczesnej gospodarki. 


\section{Teoretyczne aspekty wspótpracy}

W literaturze przedmiotu przez współpracę rozumie się powiązania między organizacjami, które zmierzają do wzajemnie niesprzecznych celów. Oznacza to tworzenie na różnych płaszczyznach powiązań, mających różny stopień trwałości i intensywności ${ }^{1}$. Powiązania mogą przybierać różny charakter, począwszy od współpracy długotrwałej i szerokiej, po wąską i jednorazową. Kształtowanie odpowiednich warunków ekonomicznych, społecznych, kulturowych i instytucjonalnych będzie stanowić czynnik wyzwalający przedsiębiorczość oraz sprzyjać współdziałaniu przedsiębiorstw, w szczególności małych i średnich w obszarze technologii.

W ostatnich latach współpraca uczelni z otoczeniem społeczno-gospodarczym stała się nie tylko tematem popularnym, ale też niezwykle ważnym z punktu widzenia rozwoju gospodarki kraju. Dziś uczelnie techniczne postrzegane są nie tylko jako źródło pomysłów i idei, które w późniejszym okresie wdrażane są przez przedsiębiorstwa, ale również jako partner, aktywnie zaangażowany w realizację wspólnych projektów badawczych.

Realia współczesnej gospodarki wymagają inwestowania w działalność badawczo-rozwojową, tym samym zwiększając rolę postępu technologicznego, a także wiedzy w procesach produkcyjnych. Międzysektorowa współpraca coraz częściej postrzegana jest jako klucz do sukcesu naukowego i przemysłowego. Z drugiej strony wciąż napotyka ona wiele barier i ograniczeń.

Mimo przeprowadzenia wielu analiz dotyczących tematyki współpracy nauki i biznesu temat ten wciąż nie jest do końca rozpoznany. W dalszym ciągu istnieje wiele wyzwań wynikających z problemów obu środowisk.

Współpraca stanowi ważny czynnik rozwoju gospodarki. Współcześnie coraz bardziej docenia się rolę i znaczenie nauki dla rozwoju gospodarczego. Małe i średnie przedsiębiorstwa stanowią źródło innowacyjności, przez którą rozumie się zdolność do implementowania, poszukiwania i dyfuzji rozwiązań. Zdolność ta przejawia się tworzeniem i doskonaleniem obecnych technologii ${ }^{2}$. W dzisiejszej gospodarce jednym z podstawowych czynników rozwoju regionów i podnoszenia innowacyjności jest tworzenie warunków do zacieśnienia współpracy między

1 A. Adamik, Powiq̨zania wspótpracy międzyorganizacyjnej w zarzq̨dzaniu współczesnymi przedsiębiorstwami, [w:] W. Kowalczewski, W. Matwiejczuk (red.), Zarządzanie organizacjami w teorii i praktyce, Wydawnictwo Difin, Warszawa 2008, s. 60-73.

2 A. Zakrzewska-Bielawska, Wspótpraca technologiczna małych i średnich przedsiębiorstw jako szansa rozwoju regionu, [w:] A. Adamik (red.), Wspótpraca matych i średnich przedsiębiorstw w regionie. Budowanie konkurencyjności firm i regionu, Wydawnictwo Difin, Warszawa 2020, s. $161-184$. 
uczelniami a przedsiębiorstwami. Zwrócenie uwagi na wymiar nauki jest szczególnie ważne, gdyż zarówno zasoby wiedzy, jak i postęp technologiczny są na wysokim stadium zaawansowania.

Z badań przeprowadzonych przez Komisję Europejską, Kodamę oraz Khalozadehiego wynika, że współpraca między nauką a biznesem stanowi siłę napędową konkurencji i innowacji ${ }^{3}$. Z kolei według Czyżewskiej rozwój przedsiębiorstw $\mathrm{w}$ istotnej mierze uzależniony jest od istnienia przedsiębiorczego środowiska, które przyczynia się do stymulowania podejmowania nowych przedsięwzięć i ich realizacji. Jego kluczowym elementem są także wyższe uczelnie, których zasadniczą rolą jest kształcenie, badanie i promowanie rozwoju gospodarczego ${ }^{4}$. Nowoczesne przedsiębiorstwa poszukują centrów naukowych oraz usług obejmujących wsparcie procesów innowacyjnych w zakresie finansowania, marketingu oraz zarządzania. Relacje między uczelniami technicznymi a przedsiębiorstwami pozwalają na lepsze zwaloryzowanie zasobów rzeczowych, kapitałowych oraz ludzkich, a także na generowanie dodatkowych efektów zewnętrznych. Przedsiębiorcy powinni być silnie związani ze środowiskiem naukowym. Tak więc rola uczelni wyższych jest istotna, ponieważ wpisuje się w nurt sfery badawczo-rozwojowej.

Jednak pomimo wielokrotnego podjęcia analizowanego tematu współpraca między nauką a biznesem stanowi wciąż dwa oddzielne obszary ${ }^{5}$. Istnieje wiele przesłanek skierowanych w stronę wdrażania działań mających na celu wzrost i zacieśnienie współpracy. W każdej z tych dwóch dziedzin tkwi ogromny potencjał. Stąd też rola i znaczenie współpracy są ogromne.

3 Good Practice in the Transfer of University Technology to Industry, Case studies by a consortium led by inno GmbH, European Innovation Monitoring System (EIMS) Publication no. 26/1995, https://cordis.europa.eu/article/id/8158-eims-case-studies-universityindus try-technology-transfer/pl (dostęp: 7.01.2020); T. Kodama, The role of intermediation and absorptive capacity in facilitating University - industry linkages an empirical study of TAMA in Japan, „Research Policy” 2008, no. 37, s. 1224-1240; F. Khalozadeh, S.A. Kazemi, M. Movahedi, G. Jandaghi, Reengineering University - Industry Interactions: Knowledge-Based Technology Transfer Model, „European Journal of Economics, Finance and Administrative Sciences" 2011, issue 40, s. 47-58.

4 D. Czyżewska, Instrumenty wspierania powiq̨zań między naukq a biznesem na przykładzie francuskiej konwencji CIFRE, „Studia Regionalne i Lokalne” 2009, nr 3, s. 121.

5 Związek Przedsiębiorców i Pracodawców, Wspótpraca naukowców i przedsiębiorców?, https://zpp.net.pl/wspolpraca-naukowcow-i-przedsiebiorcow/ (dostęp: 7.01.2020). 


\section{Materiat i metodyka badań}

Celem badania było wskazanie przez polskie uczelnie wyższe techniczne - politechniki - stanu współpracy z małymi i średnimi przedsiębiorstwami. W badaniu uczestniczyło pięć politechnik. Ankieta została przeprowadzona w formie wywiadu telefonicznego z ekspertami/brokerami współpracy między politechnikami a małymi i średnimi przedsiębiorstwami w Polsce. Przeprowadzony wywiad telefoniczny, podczas którego zadanych zostało dziesięć otwartych pytań, dotyczył współpracy między politechnikami a przedsiębiorstwami z punktu widzenia uczeni technicznych. Badania te zostały przeprowadzone w kwietniu i maju 2019 roku. Zakres czasowy obejmujący badania wynosił pięć lat. Odpowiedzi na pytania udzielali pracownicy centrów transferu technologii pracujących przy badanych politechnikach. W badaniu udział wzięły następujące uczelnie wyższe techniczne:

- Politechnika Warszawska;

- Politechnika Gdańska;

- Politechnika Poznańska;

- Półtechnika Lubelska;

- Politechnika Rzeszowska.

Wywiad miał charakter jednorazowy, a rozmówcy nie znali wcześniej pytań. Dobór ekspertów lub brokerów informacji również był losowy.

\section{Analiza wyników badanych politechnik w kontekście współpracy z małymi i średnimi przedsiębiorstwami}

Uczelnie wyższe techniczne najczęściej podejmują współpracę z branżami, które ściśle odpowiadają konkretnym wydziałom na ich uczelniach. Wszystkie poddane badaniu politechniki mają własne, specjalne, wydzielone komórki, jak centrum transferu wiedzy i technologii. Współpraca ta dotyczy przedsiębiorstw należących do branży produkcyjnej. Wyniki badania wykazały, iż politechniki wychodzą naprzeciw panującym trendom dotyczącym nawiązywania współpracy. Politechniki wskazują, iż do obowiązków pracownika centrum transferu technologii należy ustalenie zasad współpracy pomiędzy biznesem a nauką. Uczelnie te poszukują przedsiębiorców, z którymi chciałyby podjąć współpracę. Również przedsiębiorstwa zgłaszają się do politechnik, wyrażając chęć współpracy. Odbywa się to $\mathrm{w}$ formie wyszukiwania w internecie lub wysyłania zapytań o możliwość współpracy. 
Wyróżnia się wiele czynników motywujących do podjęcia współpracy - zarówno ze strony uczelni, jak i ze strony przedsiębiorców (tabela 1).

Tabela 1. Motywy współpracy uczelni wyższych technicznych z małymi i średnimi przedsiębiorstwami

\begin{tabular}{|c|c|}
\hline Nazwa uczelni & Czynniki motywujące do współpracy \\
\hline $\begin{array}{l}\text { Politechnika } \\
\text { Gdańska }\end{array}$ & $\begin{array}{l}\text { - Bardzo duży zespół naukowców z ogromnym doświadczeniem naukowym } \\
\text { i eksperckim. Wyposażenie laboratoriów. } \\
\text { - Położenie, bogata historia, znajomość uczelni w całym Pomorzu. } \\
\text { - Chęć znalezienia najlepszego rozwiązania dla danego problemu. } \\
\text { Powyższe czynniki motywujące stanowią odpowiedź na zgłaszane uczelni } \\
\text { braki zasobowe czy sprzętowe przedsiębiorstw. }\end{array}$ \\
\hline $\begin{array}{l}\text { Politechnika } \\
\text { Lubelska }\end{array}$ & $\begin{array}{l}\text { - Podjęcie nowego, ciekawego tematu z przedsiębiorcą, którego efektem jest } \\
\text { rozpoczęcie współpracy naukowej. } \\
\text { - Wzrost praktycznego wymiaru nauki. } \\
\text { - Umożliwienie bycia lepszym i bardziej praktycznym dydaktykiem. } \\
\text { - Możliwość pozyskania dodatkowych środków na dalszą działalność. }\end{array}$ \\
\hline $\begin{array}{l}\text { Politechnika } \\
\text { Warszawska }\end{array}$ & $\begin{array}{l}\text { - Chęć zrealizowania zleceń mających odwzorowanie w rzeczywistości } \\
\text { rynkowej. } \\
\text { - Zetknięcie się z rzeczywistym problemem, oczekującym konkretnej myśli } \\
\text { technologicznej, naukowej i badawczej. }\end{array}$ \\
\hline $\begin{array}{l}\text { Politechnika } \\
\text { Poznańska }\end{array}$ & $\begin{array}{l}\text { - Umożliwienie stworzenia nowego produktu, technologii. } \\
\text { - Zwiększenie szans na otrzymanie dotacji dzięki wspólnemu ubieganiu się } \\
\text { o nią. }\end{array}$ \\
\hline $\begin{array}{l}\text { Politechnika } \\
\text { Rzeszowska }\end{array}$ & $\begin{array}{l}\text { - Posiadane zasoby ludzkie. } \\
\text { - Nowe technologie. } \\
\text { - Umożliwienie poddaniu testom produktu w sytuacji, kiedy dane } \\
\text { przedsiębiorstwo nie ma takiej możliwości. }\end{array}$ \\
\hline
\end{tabular}

Źródto: opracowanie własne na podstawie wyników badań autorki.

Poddane badaniu politechniki wskazały także na szereg ograniczeń niesprzyjających podjęciu współpracy. Bariery te zostały przedstawione w tabeli 2.

Motywy współpracy, a także czynniki ją ograniczające są zbliżone we wszystkich politechnikach. Jednakże w związku z ograniczeniami współpracy powstają wyzwania. Do wyzwań wynikających ze współpracy między politechnikami a małymi i średnimi przedsiębiorstwami zaliczyć można zmniejszenie kosztów generowanych w trakcie przeprowadzania zmian w przedsiębiorstwie. Wspólne aplikowanie o dodatkowe środki na rozwój, pochodzące między innymi z Unii Europejskiej, stanowi dużą zaletę przy ubieganiu się o dotacje, jednak towarzyszą temu również wyzwania, przed którymi stoją zarówno uczelnie, jak i przedsiębiorstwa. Dlatego tak ważne jest zwrócenie uwagi na najważniejsze aspekty, dzięki którym uczelnie mogą z sukcesem współpracować z przedsiębiorstwami. Politechniki wskazały w badaniu na wiele takich kluczowych aspektów (tabela 3). 
Tabela 2. Bariery wspótpracy uczelni wyższych technicznych z małymi i średnimi przedsiębiorstwami

\begin{tabular}{|c|c|}
\hline Nazwa uczelni & Czynniki ograniczające współpracę \\
\hline $\begin{array}{l}\text { Politechnika } \\
\text { Gdańska }\end{array}$ & $\begin{array}{l}\text { - Generowanie zbyt dużych kosztów spowodowanych wprowadzeniem } \\
\text { zmian w przedsiębiorstwie, co ogranicza chęć współpracy przedsiębiorstw } \\
\text { z uczelnią. }\end{array}$ \\
\hline $\begin{array}{l}\text { Politechnika } \\
\text { Lubelska }\end{array}$ & $\begin{array}{l}\text { - Brak zrozumienia ograniczenia czasowego naukowca, dzielącego czas } \\
\text { między dydaktykę na uczelni oraz działalność badawczą. } \\
\text { - Nieporozumienia wynikające z braku czasu naukowca, który potrzebuje } \\
\text { dodatkowego czasu na dokładne zaplanowanie, przeprowadzenie } \\
\text { i ponowne zweryfikowanie danego eksperymentu. } \\
\text { - Inne nieporozumienia wynikające z próby obejścia formalnych procedur } \\
\text { (zapłata „do kieszeni”). }\end{array}$ \\
\hline $\begin{array}{l}\text { Politechnika } \\
\text { Warszawska }\end{array}$ & $\begin{array}{l}\text { - Realizacja wielu projektów badawczych w tym samym czasie. } \\
\text { - Wysoka czasochłonność działania. } \\
\text { - Odmienny sposób myślenia naukowca i przedsiębiorcy. }\end{array}$ \\
\hline $\begin{array}{l}\text { Politechnika } \\
\text { Poznańska }\end{array}$ & $\begin{array}{l}\text { - Brak możliwości oszacowania przez przedsiębiorstwa oferty - czy jest } \\
\text { rynkowa, czy przeszacowana. } \\
\text { - Oferowanie zbyt niskiego wynagrodzenia za opracowanie nowych } \\
\text { technologii. } \\
\text { - Brak czasu na realizację zleceń od przemystu w przypadku równoległego } \\
\text { realizowania własnych projektów naukowych i kontynuowania własnej } \\
\text { kariery. }\end{array}$ \\
\hline $\begin{array}{l}\text { Politechnika } \\
\text { Rzeszowska }\end{array}$ & $\begin{array}{l}\text { - Zbyt duża biurokratyzacja. } \\
\text { - Bariery formalne. } \\
\text { - Strach przed podjęciem wspótpracy przez przedsiębiorców. }\end{array}$ \\
\hline
\end{tabular}

Źródło: opracowanie własne na podstawie wyników badań autorki.

Wszystkie przedstawione kluczowe aspekty współpracy są także wyzwaniem dla obu środowisk. Podstawowym aspektem jest dobra współpraca - od momentu rozpoczęcia aż do zakończenia i wdrożenia do życia gospodarczego nowego produktu lub nowej technologii. Niezwykle ważnym aspektem jest także rozwój naukowca.

Poddane badaniu politechniki wskazały także na szereg działań, jakie podejmują w celu nie tylko nawiązania współpracy, ale przede wszystkim poznania realnych problemów i działania środowiska przedsiębiorców. Uczelnie starają się przekonać do siebie i lepszego poznania swoich możliwości. Prócz organizacji konferencji politechniki biorą udział w tematycznych targach, spotkaniach i wyjazdach branżowych. Ukazują swoje dotychczasowe rozwiązania, organizując indywidualne spotkania z przedsiębiorcami i badając ich potrzeby. Organizują dni otwartych drzwi na uczelni, innovation open day. Co więcej, prowadzone są działania w mediach, mające na celu przekazywanie informacji na temat opracowywanych rozwiązań. Zauważalne jest coraz większe uczestnictwo uczelni we wszelkiego rodzaju klastrach czy stowarzyszeniach zrzeszających centra transferu technologii. 
Tabela 3. Najważniejsze aspekty współpracy uczelni wyższej z małymi i średnimi przedsiębiorstwami z punktu widzenia uczelni technicznych

\begin{tabular}{|c|c|}
\hline Nazwa uczelni & Kluczowe aspekty współpracy \\
\hline $\begin{array}{l}\text { Politechnika } \\
\text { Gdańska }\end{array}$ & $\begin{array}{l}\text { - Dobra współpraca. } \\
\text { - Możliwość wdrożenia i najlepszego wykorzystania w gospodarce efektów } \\
\text { i wyników pracy, powodująca rozwój gospodarki krajowej. } \\
\text { - Umożliwienie wykonywania dodatkowych specjalistycznych badań. } \\
\text { - Możliwość publikowania swoich wyników. }\end{array}$ \\
\hline $\begin{array}{l}\text { Politechnika } \\
\text { Lubelska }\end{array}$ & $\begin{array}{l}\text { - Lepsze zrozumienie ograniczeń czasowych naukowca. } \\
\text { - Zrozumienie - od samego początku podjęcia współpracy - wzajemnych } \\
\text { potrzeb i oczekiwań, w celu wyeliminowania wszelkich niejasności. } \\
\text { - Dobór odpowiedniej grupy do realizacji prac badawczych. }\end{array}$ \\
\hline $\begin{array}{l}\text { Politechnika } \\
\text { Warszawska }\end{array}$ & $\begin{array}{l}\text { - Rozwiązywanie konkretnego problemu poprzez realizację projektu } \\
\text { na poziomie naukowym. } \\
\text { - Wpisanie się projektu w kompetencje i dorobek naukowy. }\end{array}$ \\
\hline $\begin{array}{l}\text { Politechnika } \\
\text { Poznańska }\end{array}$ & $\begin{array}{l}\text { - Rozwój naukowców. } \\
\text { - Osiągnięcie celów przedsiębiorstwa - nowy produkt, nowa technologia, } \\
\text { nowa usługa, nowa wiedza ekspercka. } \\
\text { - Możliwość publikowania wyników w zakresie uzgodnionym } \\
\text { z zamawiającym. }\end{array}$ \\
\hline $\begin{array}{l}\text { Politechnika } \\
\text { Rzeszowska }\end{array}$ & $\begin{array}{l}\text { - Umożliwienie przygotowania studentów do odbywania stażu } \\
\text { w przedsiębiorstwach, z którymi współpracuje. }\end{array}$ \\
\hline
\end{tabular}

Źródto: opracowanie własne na podstawie wyników badań autorki.

\section{Podsumowanie}

Przeprowadzone badania potwierdziły kluczową rolę tworzenia warunków do współpracy między politechnikami a małymi i średnimi przedsiębiorstwami. W wyniku badania wskazano wiele czynników wspierających i ograniczających współpracę między nauką a biznesem. Politechniki mają ogromne zaplecze naukowe, eksperckie i lokalowe, co niewątpliwie ułatwia współpracę z przedsiębiorcami. Dysponują możliwościami, których nie mają przedsiębiorcy. Współpraca ta powoduje, że dydaktycy dysponujący aktualną i praktyczną wiedzę z życia gospodarczego i działalności przedsiębiorstw stają się jeszcze lepsi. Zarówno przed uczelniami wyższymi, jak i przedsiębiorstwami stoi wiele wyzwań, nad którymi trzeba pracować. Dużym ograniczeniem jest brak czasu, a także zrozumienia wynikającego z innych obowiązków pracowników naukowych. Niezrozumienie problemów dzielenia czasu przez naukowca na działalność dydaktyczną oraz naukowo-badawczą powoduje wiele nieporozumień. Stanowi to kolejne wyzwanie dla podejmujących współpracę przedsiębiorstw. Zrozumienie wzajemnych potrzeb i lepsza komunikacja z pewnością przyczynią się do poprawy współpracy. Niezwykle ważnym obszarem, który stanowi duże wyzwanie, jest odpowiedni dobór grupy naukowców i pracowników 
do przeprowadzenia projektu. Odpowiedni dobór, pod względem kompetencji, czasowości i dostępności, zwiększa szansę na wykonanie projektu w zaplanowanym czasie. Współpraca daje wiele szans, chociażby poprzez wspólne powstawanie nowych pomysłów naukowych, które mogą przyczyniać się do ulepszenia gospodarki kraju. Dobranie odpowiedniej kadry do przeprowadzenia badania, a także wzajemne zrozumienie środowisk stają się ogromnymi wyzwaniami i jednymi z najważniejszych aspektów współpracy.

W celu jeszcze lepszego zacieśnienia współpracy uczelni z przedsiębiorstwami oba środowiska muszą chcieć współpracy i ją inicjować, co potwierdziły wyniki badań politechnik. Jest to niezwykle ważne, aby można było stwarzać odpowiednie warunki do wzajemnego wsparcia. Szczególnie wart podkreślenia jest fakt zmniejszenia bądź uproszczenia biurokracji związanej z podejmowaniem współpracy, która w większości przypadków bywa bardzo uciążliwa. Wzajemne relacje powinny oznaczać poszanowanie autonomii, zrozumienie funkcji i uwarunkowań prowadzenia działalności. Warto podejmować dodatkowe kroki i promować inne dobre praktyki, $\mathrm{w}$ formie lepszej adaptacji studentów do realiów pracy w przedsiębiorstwach i gospodarce, ponieważ częstym problemem jest zderzenie teorii poznanej na studiach z rzeczywistością na rynku pracy. Skoncentrowanie się na jeszcze lepszym zrozumieniu wzajemnych potrzeb, zwiększenie tolerancji oraz wzajemnego zaufania niewątpliwie przyczynią się do lepszej współpracy między podmiotami naukowymi i biznesowymi.

W dalszych badaniach warto uwzględnić perspektywę przedsiębiorstw. Poznając opinię przedsiębiorców, ich obawy i chęć podjęcia współpracy oraz najważniejsze jej aspekty, można w lepszy sposób skonfrontować oba środowiska. Ograniczeniem analizy było przebadanie jedynie pięciu politechnik. Jednak nawet tak niewielka liczba uczelni poddanych badaniu pozwoliła na wyciągnięcie ciekawych wniosków i rekomendacji na przyszłość. Aby lepiej zrozumieć złożoność i wyzwania wynikające z podejmowanej współpracy, należy poznać stanowiska obu środowisk w celu tworzenia ułatwień w podejmowaniu współpracy i zminimalizowania związanych z tym obaw. 
Bibliografia

Adamik A., Powiq̨zania wspótpracy międzyorganizacyjnej w zarzq̨dzaniu wspótczesnymi przedsiębiorstwami, [w:] W. Kowalczewski, W. Matwiejczuk (red.), Zarzqdzanie organizacjami w teorii i praktyce, Wydawnictwo Difin, Warszawa 2008, s. 60-73.

Czyżewska D., Instrumenty wspierania powiq̨zań między naukq a biznesem na przykładzie francuskiej konwencji CIFRE, „Studia Regionalne i Lokalne” 2009, nr 3, s. 120-133.

Good Practice in the Transfer of University Technology to Industry, Case studies by a consortium led by inno GmbH, European Innovation Monitoring System (EIMS) Publication no. 26/1995, https://cordis.europa.eu/article/id/8158-eims-case-studies-universityindustry-technology -transfer/pl (dostęp: 7.01.2020).

Khalozadeh F., Kazemi S.A., Movahedi M., Jandaghi G., Reengineering University - Industry Interactions: Knowledge-Based Technology Transfer Model, „European Journal of Economics, Finance and Administrative Sciences" 2011, issue 40, s. 47-58.

Kodama T., The role of intermediation and absorptive capacity in facilitating University - industry linkages an empirical study of TAMA in Japan, „Research Policy” 2008, no. 37, s. 1224-1240.

Zakrzewska-Bielawska A., Wspótpraca technologiczna małych i średnich przedsiębiorstw, jako szansa rozwoju regionu, [w:] A. Adamik (red.), Wspótpraca małych i średnich przedsiębiorstw w regionie. Budowanie konkurencyjności firm i regionu, Wydawnictwo Difin, Warszawa 2020, S. $161-184$.

Związek Przedsiębiorców i Pracodawców, Wspótpraca naukowców i przedsiębiorców?, https:// zpp.net.pl/wspolpraca-naukowcow-i-przedsiebiorcow/ (dostęp: 7.01.2020).

\section{Streszczenie}

Celem niniejszej publikacji jest przedstawienie wyników autorskiego badania poświęconego zgłębieniu tematu znaczenia współpracy uczelni wyższych technicznych w Polsce z małymi i średnimi przedsiębiorstwami, a także wyzwań wynikających z takiej współpracy. W obecnych czasach, w których wkroczenie przez polskie małe i średnie przedsiębiorstwa w erę gospodarki cyfrowej jest nieuniknione, zjawisko współpracy staje się coraz ważniejsze. W związku z tym wzrasta znaczenie poszukiwania nowych rozwiązań i obszarów współpracy, co wiąże się z nowymi wyzwaniami, przed którymi stoją oba środowiska. W badaniu wykorzystano metodę wywiadu telefonicznego. Istnieje wiele czynników motywujących do współpracy, ale prawdziwym wyzwaniem jest minimalizowanie istotnych ograniczeń mających wpływ na jej rozwój, a także tworzenie warunków do powstania współpracy.

Słowa kluczowe: współpraca, uczelnie wyższe techniczne w Polsce, małe i średnie przedsiębiorstwa, rola przedsiębiorstw w gospodarce, polskie politechniki, nowe wyzwania we współpracy 
The role, significance and challenges arising from the cooperation of technical universities and enterprises on a selected example of Polish polytechnics

\section{Abstract}

The purpose of this publication is to present the results of a proprietary study dedicated to exploring the topic of the importance of cooperation between technical universities in Poland and small and medium-sized enterprises, as well as the challenges arising from such cooperation. The phenomenon of cooperation is becoming more and more important nowadays, when the entry of Polish small and medium enterprises into the era of the digital economy is inevitable. Therefore, the importance of seeking new solutions and areas of cooperation increases, which is associated with new challenges faced by both environments. The study used the telephone interview method. There are many factors motivating cooperation, but the real challenge is to minimize significant restrictions affecting the development of such cooperation as well as creating conditions for mutual cooperation.

Keywords: cooperation, technical universities in Poland, small and medium enterprises, the role of enterprises in the economy, Polish polytechnics, new challenges in cooperation 